\title{
PEMBELAJARAN PENDIDIKAN AGAMA ISLAM SECARA TERPADU
}

\author{
Oleh:
}

\section{Zaenudin}

\begin{abstract}
Abstrak
Dalam konsep Paulo Freire seorang praktisi dan teoritisi pendidikan radikal dari Brazil, mengatakan bahwa, pendidikan yang benar adalah pendidikan yang mampu menjadi kekuatan penyadar dan pembebas manusia. Artinya, pendidikan harus bisa membebaskan dan menyadarakan manusia tentang adanya elemen-elemen yang menindas dalam struktur sosial. Dalam Islam, konsep pendidikan sebenarnya jauh lebih radikal dari konsep Paulo tersebut. Dimana manusia sebagai subyek harus memberi nama (to name) yakni ketika Allah mengajarkan nama-nama pada Adam, tujuannya adalah agar ia sadar akan esensi ciptaan, esensi sifat Tuhan, hubungan Tuhan dengan ciptaan-Nya, dan manusi terpilih menjadi khalifah di dunia sebagai pembawa kedamaian.Karena itu, konsepsi dan filosofi pendidikan Islam sejak awal tidak hannya bersumber dari intelektualitas semata, melainkan juga spritualitas, dan tujuan akhir dari sebuah pendidikan adalah sang Pencipta. Untuk menjawab persoalan dan tujuan dari sebuah pendidikan, maka pada tulisan ini penulis mencoba untuk membahas tentang; apa itu pendidikan Islam, konsep pendidikan Islam terpadu, format pendidikan terpadu dan bagaimana frofil lulusan sekolah terpadu.
\end{abstract}

Kata Kunci: Pendidikan, Agama Islam, Terpadu

\section{A. PENDAHULUAN}

Masyarakat global saat ini dihadapkan pada hal yang sangat serius, yaitu pengaruh sistem nilai sekuler dan materialis. Semua lapisan masyarakat,baik orang tua, pendidik, agamawan sedang berfikir tentang bagaimana cara terbaik untuk mendidik generasi muda dan mempersiapkan mereka menghadapi tantangan global dimasa mendatang.

Diantara mereka ada yang memberikan solusi dengan menggunakan metode pendidikan masa lalu(pola pesantren an-sich) dan diantara mereka ada yang menggunakan metode pendidikan barat secara an-sich. Namun diatasa semua itu sesungguhnya semua orang membutuhkan perbaikan dan rekonstruksi konsep 
pendidikan menuju masa depan generasi yang gemilang didunia dan akherat ( shaleh secara spritual dan shaleh secara sosial).

Bagaimana memberikan pendidikan terbaik bagi generasi yang akan datang dan generasi sekarang ini, maka praktisi pendidikan harus membuat berbagai macam pertanyaan seperti, bagaimana kita memformat dunia pendidikan yang handal, yang bisa mengantar anak didik berkualiatas, efektif, efisien dan bisa diterima oleh zamannya.

Masa depan generasi, dan masyarakat kita sangat tergantung pada jawaban yang kita berikan pada pertanyaa-pertanyaan tersebut secara tepat dan sejauh mana kita sukses mentransfer visi kehidupan yang tepat untuk generasi kita.

Fenomena yang muncul dalam masyarakat muslim saat ini adalah semakin melonggarnya ikatan-ikatan norma, baik norma sosial, norma agama dan normanorma yang lainnya. Seperti kasus amoral yang dilakukan oleh "generasi" kita (mabuk, sex bebas, tawuran), pejabat pemerintah banyak yang korupsi dan kejahatankejahatan lainnya.

Problem-problem tersebut harus diberikan jawaban yang tepat dan akurat serta harus kita mencari apa dibalik semua fenomena itu. Salah satu jawaban yang mungkin mampu memberikan solusi adalah para intelektual muslim sekarang harus mampu melakukan reoreientasi dalam menatap persoalan pendidikan. Reorientasi atau rekonstruksi konsep pendidikan sangat penting, karena tanpa itu, maka kita tidak akan pernah mampu memberikan solusi, membesarkan generasi kita sesuai dengan zamannya.

Di dalam Undang-Undang Nomor 20 tahun 2003 tentang Sisdiknas pasal 1 ayat (1) dinyatakan pendidikan adalah usaha sadar dan terencana untuk mewujudkan suasana belajar dan proses pembelajaran agar peserta didik secara aktif mengembangkan potensi dirinya untuk memiliki kekuatan spritual keagamaan, 
pengendalian diri, kepribadian, kecerdasan, akhlak mulia, serta keterampilan yang diperlukan dirinya, masyarakat, bangsa dan negara.

Pada pasal 1 ayat (2) dinyatakan, bahwa pendidikan nasional adalah pendidikan yang berdasarkan pancasila dan Undang-Undang Dasar 1945 yang berakar pada nilai-nilai agama.

Untuk mewujudkan Undang-Undang tersebut, maka para praktisi harus mampu memberikan solusi terbaik dalan desain pendidikan nasional, dimana desain itu akan dijadikan pijakan oleh para guru. Maka menurut analisis penulis kurikulum merupakan salah satu elemen penting dalam pendidikan. Kurikulum yang mampu mencetak peserta didik menjadi insan kamil adalah terintegralnya konsep kurikulum umum dengan kurikulum pendidikan agama/kurikulum terpadu.

\section{Rumusan Masalah.}

Dengan uraian diatas, maka penulis dapat rumusan masalah sebagai berikut.

1. Bagaimana Hakekat Pendidikan Islam

2. Bagaimana Paradigma Pendidikan Agama Islam Terpadu.

\section{B. KAJIAN PUSTAKA}

\section{Hakekat Pendidikan Islam}

Menurut Muhaimin, bahwa pendidikan Islam merupakan pendidikan yang Islami, pendidikan yang dijiwai oleh nilai-nilai Islam atau yang dipaham dan dikembangkan dari ajaran dan nilai-nilai fundamental yang terkandung dalam sumber dasarnya yaitu, al-Qur'an dan Hadits Nabi.(Muhaimin:2009:70).

Pendidikan Islam adalah pendidikan yang melatih sensibilitas siswa sedemikian rupa, sehingga dalam perilaku mereka terhadap kehidupan, langkah-langkah dan keputusan, begitu pula pendekatan mereka terhadap semua ilmu pengetahuan, diatur oleh nilai-nilai etika Islam yang sagat mendalam. (Ali Ashraf:1996:23). 
Istilah pendidikan Islam dapat dipahami dari tiga sudut pandang, yaitu pendidkan agama Islam, pendidikan dalam Islam, pendidikan menurut Islam. Dalam kerangka akademik, ketiga sudut pandang itu harus dibedakan dengan tegas, karena ketiganya akan melahirkan disiplin ilmu tersendiri. Pendidikan agama Islam menunjuk kepada proses operasianal dalam usaha pendidikan ajaran-ajaran agama Islam. Pendekatan inilah yang menjadi kajian ilmu pendidikan islam teoritis. Pendidikan dalam Islam bersifat sosiohistoris, dan menjadi bahan kajian dalam sejarah pendidikan islam, sedangkan pendidikan menurut Islam bersifat normatif dan menjadi bahan kajian filsafat pendidikan Islam.( Tajab:1999:24-25).

Konsepe pendidikan Islam dimulai dengan konsep tentang manusia. Hal ini terlihat sagat jelas dalam surat al-Baqarah ayat 31 dan 32 yang menceritakan bagaimana Allah mengajarkan kepada Adam nama-nama benda, kemudian Adam mengajarkan nama-nama benda itu kepada para Malaikat .

Ketika Allah mengajarkan pada Adam nama-nama benda, tujuannya bukan hanya agar ia tahu dan mengerti, tetapi sadar akan esensi ciptaan, sadar akan sifat-sifat Allah dan antara hubungan Allah dengan ciptaan-Nya. Integrasi kesadaran intelektual dengan kesadaran spritual inilah yang menjadi dasar konsep pendidikan Islam sejak awal. Konsep pendidikan Islam sudah setua umur manusia itu sendiri. Konsep pendidikan Islam dibangun atas dasar metafisika atau ontologi, dimana hubungan Allah sebagai pencipta dan manusia sebagai subyek berada dalam suatu rangkaian orientasi religius dan kerangka etis(aksiologi). Manusia dalam konsepsi pendidikan Islam akan mencapai tujuannya sebagai wakil Allah dimuka bumi dan dapat menggunakan ilmu pengetahuan yang diberikan untuk kepentingan ummat manusia itu sendiri. Manusia pada dasarnya adalah makhluk spritual, karena manusia sejak awal sejarahnya sudah didik oleh sang Pencipta.

Dalam konsep Paulo Freire seorang praktisi dan teoritisi pendidikan radikal dari Brazil, mengatakan bahwa, pendidikan yang benar adalah pendidikan yang mampu menjadi kekuatan penyadar dan pembebas manusia. Artinya, pendidikan harus bisa membebaskan dan menyadarakan manusia tentang adanya elemen-elemen yang menindas dalam struktur sosial.( Paulo Friere:1985:27). 
Dalam Islam, konsep pendidikan sebenarnya jauh lebih radikal dari konsep Paula tersebut. Dimana manusi sebagai subyek harus memberi nama (to name) yakni ketika Allah mengajarkan nama-nama pada Adam, tujuannya adalah agar ia sadar akan esensi ciptaan, esensi sifat Tuhan, hubungan Tuhan dengan ciptaan-Nya, dan manusi terpilih menjadi khalifah di dunia sebagai pembawa kedamaian.

Karena itu, konsepsi dan filosofi pendidikan Islam sejak awal tidak hannya bersumber dari intelektualitas semata, melainkan juga spritualitas, dan tujuan ahir dari sebuah pendidikan adalah sang Pencipta.

Dan perlu diingat bahwa manusia dikatakan juga sebagai makhluk yang mempuyai raga dan jiwa (monodualisme). Atas dasar monodualisme itulah, maka pendidikan akan menyelaraskan pemenuhan kebutuhan-kebutuhan baik yang menyangkut kebutuhan jasmani maupun kebutuhan rohani, baik ataupun buruk, indah atau tidak indah. Pendidikan akan memberikan petunjuk agara didalam hidupnya manusia perlu dipenuhi kebutuhan hidupnya, tanpa merugikan orang laian. Dan manusia harus sadar bahwa tatkala kebutuhannya bisa terpenuhi, maka itu bukan semata-mata sepenuhnya usahanya, melainkan ada unsur Tuhan didalam usahanya itu, maka manusia harus taat pada-Nya.

Pendidikan yang digambarkan pada manusia dan diajarkan oleh al-Qur'an mempuyai beberapa aspek, seperti.Pendidikan yang berkarekteristik keimanan pada yang Maha Segalanya. Pendidikan yang mengajarkan aspek amaliah yang membawa kebaikan didunia dan akherat bagi bagi individu dan masyarakat.

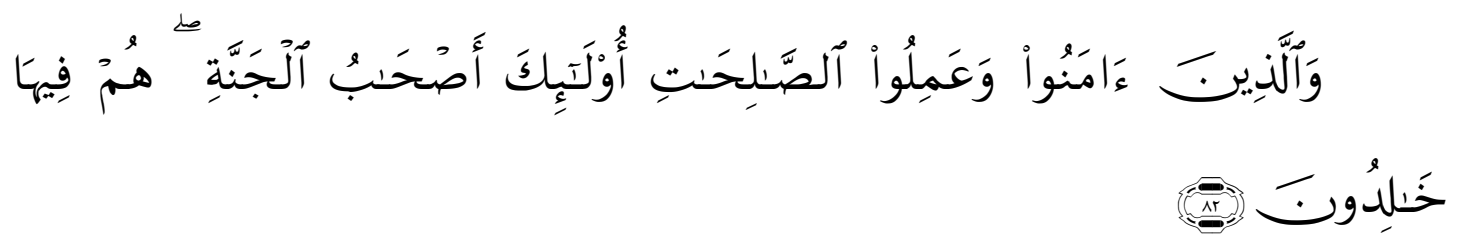

82. Dan orang-orang yang beriman serta beramal saleh, mereka itu penghuni surga; mereka kekal di dalamnya.

Pendidikan Islam mengajarkan tentang akhlak terhadap sang Pencipta, akhlah sesama makhluk dan didalam pendidikan Islam akhlak merupakan salah satu tolak ukur penilaian 
keimanan seseorang, dan Rasul S.A.W. diutus kedunia ini untuk meyempurnakan akhlak manusia.

Pendidikan Islam tidak hannya mengajarkan sholeh secara spritual semata, namun pendidikan Islam melalui al-Qur'an mengajarkan kesalehan secara sosial, karena manusia itu sendiri merupakan makhluk sosial.

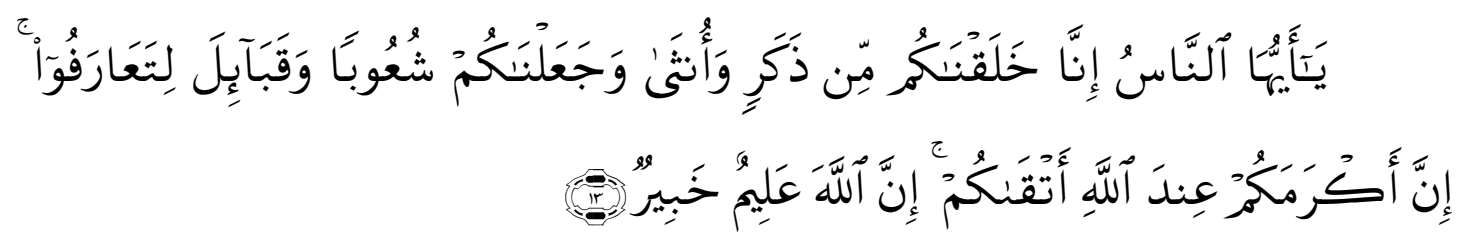

13. Hai manusia, Sesungguhnya kami menciptakan kamu dari seorang laki-laki dan seorang perempuan dan menjadikan kamu berbangsa - bangsa dan bersuku-suku supaya kamu saling kenal-mengenal. Sesungguhnya orang yang paling mulia diantara kamu disisi Allah ialah orang yang paling taqwa diantara kamu. Sesungguhnya Allah Maha mengetahui lagi Maha Mengenal.

Di dalam pendidikan Islam ada beberapa prinsip, yaitu pendidikan Islam merupakan bagian dari sistem kehidupan Islam, yaitu suatu proses internalisasi dan sosialisasi nilai-nilai moral Islam melalui sejumlah informasi, pengetahuan, sikap, prilaku dan budaya. Pendidikan Islam merupakan sesuatu yang integrated artinya mempuyai kaitan yang membentuk suatu kesatuan yang integral dengan ilmu-ilmu yang lain. Pendidika Islam merupakan life long process sejak dini kehidupan manusia. Pendidikan Islam berlangsung melalui proses yang dinamis, yakni harus mampu menciptakan iklim yang dialogis dan interaktif antara pendidik dan peserta didik. Pendidikan Islam banyak memberikan pesan-pesan moral pada peserta didik.(Zainudin: 2008:89).

Menurut Muhaimin (Muhaimin:2009:14-15) bahwa inti pendidikan Islam itu ada dua, yaitu Pertama. Pendidikan Islam merupakan aktivitas pendidikan yang diselenggarakan atau didirikan dengan hasrat dan niat untuk mengejawantahkan ajaran dan nilai-nilai Islam. Kedua. Pendidikan Islam adalah sistem pendidikan yang dijiwai oleh ajaran dan nilai-nilai Islam, maka dalam pengertian ini pendidikan Islam dapat mencakup 1. Kepala sekolah, pimpinan perguruan tinggi disemagati oleh nilai-nilai Islam, begitupun dengan sarana 
prasarana penunjang lainnya. 2. Komponen-komponen aktivitas pendidikan, seperti kurikulum, peserta didik, guru harus dijiwai oleh nilai-nilai Islam.

Islam sebagai agama yang sempurna telah memberikan pijakan yang jelas tentang tujuan dan hakekat pendidikan, yaitu memberdayakan potensi fitrah manusia secara utuh (integral) baik secara jasmani maupun rohani dan akal agar dapat menjalankan fungsinya sebagai hamba Allah yang mengabdi dan setia lewat ibadah kepada-Nya.

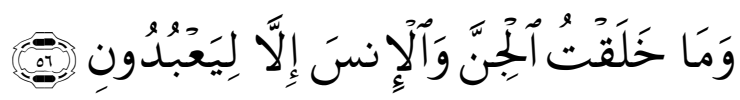

artinya: Aku tidak menciptakan jin dan manusia melainkan supaya mereka mengabdi kepada-Ku.(QS.al-Dzariyat:56).

\section{Paradigma Pendidikan Agama Islam Terpadu}

Pendidikan agama Islam terpadu bisa dilakukan dengan syarat bahwa dua sistem pendidikan yang ada dilebur menjadi satu sistem dan mempuyai filosofi yang sama yaitu filosofinya tetap Islam.

Bersamaan dengan hal tersebut diatas, kurikulum dilandasi dengan nilai-nilai keIslaman. Setiap pelajar harus mempuyai pengetahuan dasar yang diperlukan sebagai seorang muslim, dan pengetahuan tersebut harus terintegral dalam bingkai nilai-nilai Islami, pengembangan buku teks yang Islami serta metode pengajarannyapun berdasarkan Islam.

Tantangan pendidikan Islam adalah mencari sistem pendidikan sintesis dari berbagai sistem pendidikan yang telah ada, yaitu pendidikan terpadu yang lebih menitik beratkan pada aspek keseimbangan: Afektif, kognitif, psikomotorik.

Di dalam Undang-Undang Nomor 20 tahun 2003 tentang Sisdiknas pasal 1 ayat (1) dinyatakan pendidikan adalah usaha sadar dan terencana untuk mewujudkan suasana belajar dan proses pembelajaran agar peserta didik secara aktif mengembangkan potensi dirinya untuk memiliki kekuatan spritual keagamaan, 
pengendalian diri, kepribadian, kecerdasan, akhlak mulia, serta keterampilan yang diperlukan dirinya, masyarakat, bangsa dan negara.(UU. No.20:2003).

Pada pasal 1 ayat (2) dinyatakan, bahwa pendidikan nasional adalah pendidikan yang berdasarkan pancasila dan Undang-Undang Dasar 1945 yang berakar pada nilai-nilai agama.

\section{Konsep Filosifis Pendidikan Islam Terpadu.}

Al-Qur'an dan Hadits merupakan kebenaran mutlak bagi seorang muslim, alQur'an sebagai ayat qauliyah tadiwiniyyah yang bersifat deduktif memberikan informasi ilmiah kepada manusia tentang fenomena alam semesta, begitu juga dengan ayat-ayat kauniyah yang bersifat induktif. Sementara itu, filsafat dan ilmu pengetahuan sebagai produk akal manusia harus mengungkap kebenaran wahyu tersebut secara terus menerus, sehingga kebenarannya terus terkuak dan dapat disebarkan ke masyarakat.

Wahyu harus terus menerus dikaji sehingga melahirkan sebuah ilmu. Dengan demikian ilmuan diharapkan mampu memperoleh informasi ilmiah dari wahyu yang bersifat qauliyah-tadwiniyyah.

Filsafat sebagai metode berfikir rasional bertugas melakukan perenungan terus menerus tentang alam semesta beserta isinya. Sementara ilmu sebagai metode berfikir rasional-empiris bertugas mencari bukti kebenaran qauliyah Allah. Masalahmasalah perenunga dikaji melalui filsafat dan sementara masalah-masalah yang mampu diferifikasi secara empirik dikaji melalui ilmu.

Di dalam al-Qur'an dikatakan bahwa, segala yang ada didunia ini berasal dari air, dan konsep ini dibenarkan oleh para ilmuan. 


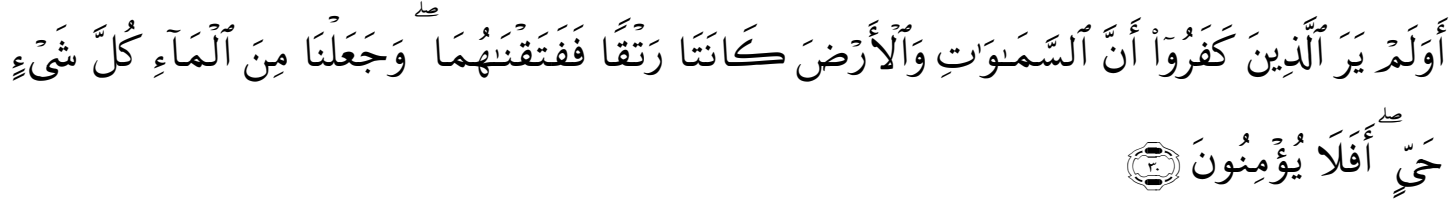

30. Dan apakah orang-orang yang kafir tidak mengetahui bahwasanya langit dan bumi itu keduanya dahulu adalah suatu yang padu, Kemudian kami pisahkan antara keduanya. dan dari air kami jadikan segala sesuatu yang hidup. Maka mengapakah mereka tiada juga beriman?. ( al-Anbiya':30).

Begitupun temuan-temuan ilmiah lainnya harus dicarikan dalil dari al-Qur'an, supaya kebenarannya dapat diimani.Elaborasi terhadap konstruk-konstruk teoritis alQur'an inilah yang hakekatnya merupakan kegiatan Qur'anic-theory building yang pada gilirannya melahirkan paradigma al-Qur'an. Fungsi paradigma al-Qur'an pada dasarnya adalah untuk membangun persepektif al-Qur'an dalam rangka memahami realitas. ( Quraish Shihab:2002:60).

Islam sebagai agama yang sempurna telah memberikan pijakan yang jelas tentang tujuan dan hakekat pendidikan, yaitu memberdayakan potensi fitrah manusia secara utuh (integral) baik secara jasmani maupun rohani dan akal agar dapat menjalankan fungsinya sebagai hamba Allah yang mengabdi dan setia lewat ibadah kepada-Nya.

Dalam ajaran Islam tidak ada pembedaan antara ilmu umum dan ilmu agama (dikotomi). Kedua ilmu tersebut harus disatuakan dalam satu konsep yang terintegral dengan baik, agar fungsi khalifah dan abid dapat terlaksana dengan baik dan maksimal.

Nabi S.A.W. telah menginstruksikan pada ummatnya, bahwa barang siapa yang ingin dunia, maka dengan ilmu, barang siapa yang ingin akhirat dengan ilmu dan barang siapa yang ingin kedua-duanya dengan ilmu(HR.Ahmad). 
Berpijak pada konsep tersebut, maka pendidikan Islam berusaha memadukan unsur dunawiyah dan unsur ukhrawiyah, karena pendidikan merupakan suatu proses membina seluruh potensi manusia sebagai makhluk yang beriman dan bertakwa, berfikir dan berkarya untuk kemaslahatan diri dan lingkungannya dan mmenyiapkan mereka untuk merealisasikan fungsi kehambaan pada Allah dan misi kekhalifahannya di muka bumi sebagai makhluk yang memakmurkan kehidupan bersama dengan aman, damai dan sejaahtera.

Dari landasan filosofis yang tergambarkan diatas, maka dalam sejarah Islam telah membuktikan sebagai ummat yang memeiliki peradaban yang gemilang, zaman ke-emasan dengan kemajuan ilmu pengetahuan dan teknologi, bahkan mengungguli kejayaan Barat pada zamanya. Islam telah mencetak sarjana-sarjana yang luar biasa dan mereka terkenal sampai sekarang ini, seperti Ibnu Sina, al-Farabi, al-Kindi, alRazi dan ratusan ilmuan lainnya.

Filsafat pendidikan yang memadukan pendidikan Islam dan sains modern harus berangkat dari cita-cita al-Qur'an dan Hadits tentang manusia, serta kegiatan pendidikan yang tercermin secara jelas dalam rumusan filsafat pendidikannya. Dengan demikian kegiatan pendidikan mempuyai makna spritual yang mengatasi ruang dan waktu.

Filsafat pendidikan terpadu berangkat dari filsafat pendidikan teosetris, yang menurut Mastuhu mempuyai beberapa ciri. Pertama. Mengandung dua jenis nilai: Wahyu Allah dan nilai kebenaran relatif hasil penafsiran manusia terhadap wahyu Tuhan. Kedua. Nilai itu mempuyai hubungan herarkis, yakni nilai absolut yang merupakan supermasi terhadap kebenaran relatif, nilai relatif tidak bertentangan dengan nilai absolut. (Mastuhu:1994:16-17)

\section{METODE PENELITIAN}

Penelitian ini berjenis kajian pustaka yang mengkombinasikan konsep pendidikan dari para praktisi pendidikan dan formulasikan dengan beberapa 
konsep yang ada dalam al-Qur'an dan hadist Nabawi, karena sejarah mencatat bahwa Pendidikan Islam yang telah mewarnai dan memberikan spesifikasi dalam segala bidang keilmuan yang sudah terbukti sampai saat ini.

\section{PEMBAHASAN}

\section{Format Pendidikan Terpadu.}

Dalam rangka membangun pendidikan yang mampu melahirkan sumber daya manusia seutuhnya dan berkualitas, baik material maupun spritual, maka diperlukan sistem pendidikan yang integral dan dinamis.

Implementasi pandangan tersebut, maka harus dikembangkan melalui pilarpilar fitrah manusia yang dibungkus dengan ruh Ilahiyah baik dalam hal kognitif, afektif, psikomotorik peserta didik. Artinya pendidikan terpadu yang dikembangkan dalam Islam bukan sekedar proses pendidikan searah, tetapi proses pendididkan multidimensi untuk kehidupan dunia dan akherat, yaitu proses pengembangan jasmani dan rohani serta intelektual.

Pendidikan Islam terpadu memandang manusia dari prinsip ketauhidan pada Allah, dan memandang alam semesta sebagai suatu sistem terpadu dan berkesinambungan dengan dimensi psikologis dan psikis manusia. Dengan dimensi ini manusia akan mampu untuk tidak berbuat mafsadat.

Untuk mencapai hal-hal tersebut diatas, maka perlu adanya format pendidikan terpadu sebagai berikut.

\section{Keterpaduan Tujuan dan Jenjang Pendidikan.}

Tujuan pendidikan Islam adalah membina manusia agar mampu menjalankan fungsinya sebagai abid dan khalifah Allah. Pembinaan akalnya akan menghasilkan ilmu, sedangkan pembinaan jasmaninya akan menghasilkan keterampilan dan pembinaan jiwa yang menghasilakan akhlak yang dilakukan secara integral. 
Dalam pendidikan Islam terpadu rumusan tujuan didasarkan pada keterpaduan beberapa aspek, yaitu.

1. Tujuan hidup manusia. Misi hidup manusia adalah dunia dan akhirat, karena hidup ini bukan kebetulan, namun sudah dirancanag sedemikian rupa oleh Allah sebagai abid dan khalifahnya, dan harus difungsikan secara seimbang.

2. Memperhatiakan sifat-sifat fitrah manusia baik jasmani maupun rohani, akal dan kebutuhan individu maupun keluarga.

3. Memperhatikan tuntutan sosial masyarakat baik berupa pelestarian budaya dan kebutuhan hidup lainnya.(Fathur Rahman:2004:211)

\section{Keterpaduan Keilmuan}

Persoalan klasik pendidikan nasional kita adalah adany pemisahan ilmu agama dan ilmu umum(dikotomi), hal ini yang menyebabkan peserta didik berpenampilan ganda. Dalam konsep pendidikan Islam tidak ada istilah dikotomi dalam keilmuan, karena semua ilmu itu bermuara pada yang kuasa yaitu Allah. Akan tetapi dalam Islam sumber ilmu itu ada yang berasal dari wahyu dan ada yang berasal dari akal manusia.Lalu siapa yang memberikan akal?.

Menurut Yusuf Qardhawai, bahwa dikotomi lahir dari dunia Barat, khususnya Eropa yang jauh dari nilai-nilai ke-Islaman. Islam mendorong dan memotivasi manusia untuk senantiasa berada dalam proses belajar-mengajar dan spirit yang mampu melahirkan sebuah peradaban besar yang dibangun diatas teori dan metode ilmiah, sehingga mampu mengungkap nilai-nilai peradaban yang humanis untuk diimplementasikan dalam pergaulan hidup sehari-hari.( Yusuf Qaedhawi:2003:40)

Pandangan dikotomi mempuyai implikasi terhadap pengembangan pendidikan agama Islam yang lebih beroirentasi pada kehidupan akhirat, sedangkan masalah dunia dianggap tidak penting, dan menekankan pada pendalaman ilmu-ilmu keagamaan yang merupakan jalan pintas menuju kebahagiaan akherat, sementara 
sains dianggap terpisah dari agama. Pendekatan keagamaan lebih bersifat normataif, doktriner, absolutis.(Muhaimin. Of.Cit.61).

\section{Ketrpaduan Kurikulum Pendidikan.}

Dalam pendidikan Islam, kurikulum juga dipandang sebagai suatu hal yang sangat esensi, melalui desain kurikulum menjadi titik tolak bagaimana pendidikan tersebut kedepan. Pendidikan Islam terpadu memerlukan model kurikulm integral yang mampu memformulasikan semua tindakan enduktif dalam suasana dinamis, bersifat pleksibel, terbuka serta merangsang ke-fitrahan manusia itu. Materi kurikulm harus mampu menyentuh semua fitrah siswa, baik fitrah rohani, jasmani serta akal dan perasaan, sehingga memberi corak kehidupan dimuka bumi ini.

Melalui kurikulum terpadu itu akan melahirkan. 1. Melalui kurikulum terpadu akan melahirkan out put yang mempuyai pengamatan terpadu. 2. Melalui kurikulum terpadu dapat menghasilkan manusia yang memiliki perkembangan dan kepribadian yang integral dan seimbang. 3. Kurikulum terpadu dapat menghasilakan manusia sosial sebagai anggota masyarakat atas ikatan-ikatan budaya, agama, adat yang berhubungan secara dinamis, harmonis, baik hubungan vertikal maupun horizontal. (zainudin.Of.cit.56).

Integrasi kurikulum terpadu itu dapat dilakukan secara kualitatif dan kuantitatif. Secara kuantitatif bisa dilakukan dengan memberikan prosentasi pelajaran umum dengan agama secara seimbang, sedangkan secara kualitatif, dengan menjadikan pendidikan umum diperkaya dengan nilai-nilai agama, dan pelajaran agama diperkaya dengan muatan yang ada dalam pendidikan umum (Fahmi Alaydroes:2003:4).

Bentuk-bentuk kurikulum terpadu bisa mengacu dari konsep integrated curiculum, yang dapat dilakukan dengan bentuk. 1. Keterpaduan dalam satu disiplin ilmu. 2. Keterpaduan dalam lintas bidang studi. 3. Keterpaduan dalam dan lintas siswa.(Zainuddin.Of. cit.57). 
Keterpaduan iptek dan imtaq dapat dibagun dengan cara seperti, mengaitkan nilai-nilai agama tersebut kedalam pelajaran umum. Contoh pada bidang geografi pada bab yang berbicara tentang problem kependudkan, kelestarian lingkungan, bagaimana ajaran Islam mengatur permasalahan tersebut, maka seorang guru bisa membuka al-Qur'an surat al-Qashas:77.

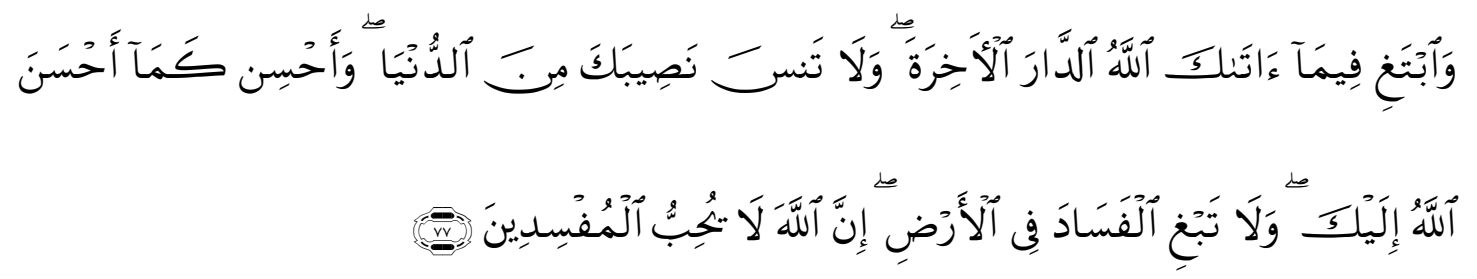

77. Dan carilah pada apa yang Telah dianugerahkan Allah kepadamu (kebahagiaan) negeri akhirat, dan janganlah kamu melupakan bahagianmu dari (kenikmatan) duniawi dan berbuat baiklah (kepada orang lain) sebagaimana Allah Telah berbuat baik, kepadamu, dan janganlah kamu berbuat kerusakan di (muka) bumi. Sesungguhnya Allah tidak menyukai orang-orang yang berbuat kerusakan.

Di dalam Undang-Undang Nomor 20 tahun 2003 tentang Sisdiknas pasal 1 ayat (1) dinyatakan pendidikan adalah usaha sadar dan terencana untuk mewujudkan suasana belajar dan proses pembelajaran agar peserta didik secara aktif mengembangkan potensi dirinya untuk memiliki kekuatan spritual keagamaan, pengendalian diri, kepribadian, kecerdasan, akhlak mulia, serta keterampilan yang diperlukan dirinya, masyarakat, bangsa dan negara.

Pada pasal 1 ayat (2) dinyatakan, bahwa pendidikan nasional adalah pendidikan yang berdasarkan pancasila dan Undang-Undang Dasar 1945 yang berakar pada nilai-nilai agama.

Dengan adanya Undang-Undang tersebut, kita bisa menarik suatu pemahaman bubahwa, pendidikan Islam bukan hanya tugas guru agama semata, tetapi menjadi tugas bersama antara kepala sekolah, guru agama, guru umum, seluruh 
aparatur sekolah dan begitu juga wali murid harus. Jika demikian, maka pendidikan Islam disekolah harus dikembangkan menjadi budaya sekolah sebagaimana tertuang dalam Undang-Undang tersebut.

\section{Profil Lulusan Sekolah Terpadu.}

Menurut Muhaimin, bahwa profil lulusan sekolah terpadu itu sangat sederhana dan dapat dijabarkan dalam do'a sehari-hari, di dalam surat al-Furqan Allah berfirman:

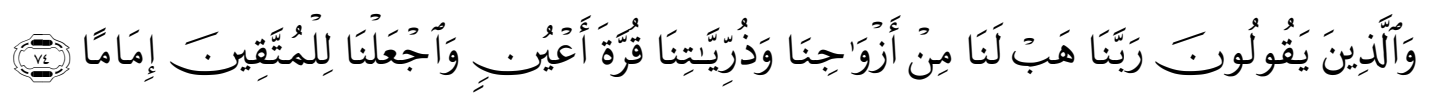

74. Dan orang orang yang berkata: "Ya Tuhan kami, anugrahkanlah kepada kami isteri-isteri kami dan keturunan kami sebagai penyenang hati (Kami), dan jadikanlah kami imam bagi orang-orang yang bertakwa.

Kedua orang hendaknya selalu berdoa, agar anak keturunannya menjadi

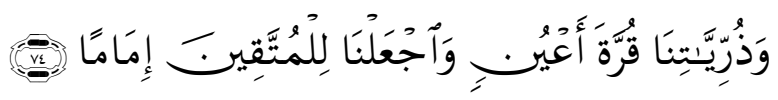

Masalahnya apa yang dimaksudkan dengan zurriyah qurrata 'ayun dan imam li al-muttaqin.Zurriyah qurrat 'ayun yaitu kader-kader yang menjadi imam li almuttaqin. Dengan demikian imam li al-muttaqin merupakan kesinambungan dari zurriyah qurrt 'ayun. Untuk memahami prifil imam li al-muttaqin, maka kita perlu mengkaji makna dan esensi takwa itu sendiri. Makna takwa itu ada dua macam, yaitu ittiba' syari'atillah (mengikuti ajaran Allah yang tertuang dan terkandung dalam alQur'an dan Sunnah S.A.W. dan yang kedua adalah ittiba' sunnatillah yaitu, mengikuti aturan-aturan Allah yang berlaku di alam semesta ini.(Muhaimin.Of.cit:107). 


\section{6 .Analis dan Kritik.}

Kurikulum merupakan sesuatu yang sangat pundamental di dalam dunia pendidikan, maka desain kurikulum merupakan salah satu solusi yang tepat untuk menjawab permasalahan pendidikan, kurikulum yang terintegral antara pelajaran umum dan pelajaran agam(kurikilum terpadu) adalah satu-satunya sistem yang bisa menghantarkan anak didik kita menjadi manusia yang shloeh secara spritual dan shaleh secara sosial, karena disetiap pelajaran umum akan dikaji juga dengan semangat nilai-nilai ke-Islaman, begitu juga sebaliknya bahwa, setiap pelajaran agam akan dipadukan juga dengan keilmuan-keilmuan umum. Dalam ajaran Islam tidak ada ada istilah dikotomi ke-Ilmuan. Tampa pengintegralan kurikulum dalam dunia pendidikan, maka sejarah telah mencatat hasil pendidikan kita masih rendah bahkan jauh dari apa yang diharapkan. Kita lebih senang menggunakan desain-desain kurikulum barat yang dianggap maju, namun apa yang terjadi, sekian permasalahan anak bangsa ini kita baca, degar mmelalui media massa, sebagian mereka terjerumus dalam dunia hitam, tawuran antar pelajar, bahkan dikalangan mahasiswa yang kita anggap sebagai calon-calon intelektual masih banyak yang terjerumus dalam dunia hitam, semakin tinggi ke-ilmuan mereka, semakin tinggi amoral yang mereka lakukan, salah satu penyebabnya adalah karena desain kurikulum yang diajarkan sangat sedikit yang menyentuh banthin, jiwa mereka, mereka lebih banyak dipersiapkan secara kognetif, namun afektif, psikomotorik mereka sungguh jarang disentuh. Kita bangga kalau anak kita mempuyai nilai 9 dalam bidang studi yang di UN-kan, tapi kita lupa bagaimana moral mereka. Hannya konsep Allah yang paling sempurna, Kurikulum Allah yang paling baik, hanya dengan nilai-nilai ke-Islaman yang terintegral yang mampu menjawab pendidikan kita. Amin.

\section{E. KESIMPULAN}

Pendidikan Islam adalah pendidikan yang melatih sensibilitas siswa sedemikian rupa, sehingga dalam perilaku mereka terhadap kehidupan, langkah- 
langkah dan keputusan, begitu pula pendekatan mereka terhadap semua ilmu pengetahuan, diatur oleh nilai-nilai etika Islam yang sagat mendalam

Al-Qur'an dan Hadits merupakan kebenaran mutlak bagi seorang muslim, alQur'an sebagai ayat qauliyah tadiwiniyyah yang bersifat deduktif memberikan informasi ilmiah kepada manusia tentang fenomena alam semesta, begitu juga dengan ayat-ayat kauniyah yang bersifat induktif. Sementara itu, filsafat dan ilmu pengetahuan sebagai produk akal manusia harus mengungkap kebenaran wahyu tersebut secara terus menerus, sehingga kebenarannya terus terkuak dan dapat disebarkan ke masyarakat

Filsafat pendidikan terpadu berangkat dari filsafat pendidikan teosetris, yang menurut Mastuhu mempuyai beberapa ciri. Pertama. Mengandung dua jenis nilai: Wahyu Allah dan nilai kebenaran relatif hasil penafsiran manusia terhadap wahyu Tuhan. Kedua. Nilai itu mempuyai hubungan herarkis, yakni nilai absolut yang merupakan supermasi terhadap kebenaran relatif, nilai relatif tidak bertentangan dengan nilai absolut

Implementasi pandangan tersebut, maka harus dikembangkan melalui pilarpilar fitrah manusia yang dibungkus dengan ruh Ilahiyah baik dalam hal kognitif, afektif, psikomotorik peserta didik. Artinya pendidikan terpadu yang dikembangkan dalam Islam bukan sekedar proses pendidikan searah, tetapi proses pendididkan multidimensi untuk kehidupan dunia dan akherat, yaitu proses pengembangan jasmani dan rohani serta intelektual.

Menurut Yusuf Qardhawai, bahwa dikotomi lahir dari dunia Barat, khususnya Eropa yang jauh dari nilai-nilai ke-Islaman. Islam mendorong dan memotivasi manusia untuk senantiasa berada dalam proses belajar-mengajar dan spirit yang mampu melahirkan sebuah peradaban besar yang dibangun diatas teori dan metode ilmiah, sehingga mampu mengungkap nilai-nilai peradaban yang humanis untuk diimplementasikan dalam pergaulan hidup sehari-hai.

Melalui kurikulum terpadu itu akan melahirkan. 1. Melalui kurikulum terpadu akan melahirkan out put yang mempuyai pengamatan terpadu. 2. Melalui kurikulum 
terpadu dapat menghasilkan manusia yang memiliki perkembangan dan kepribadian yang integral dan seimbang. 3. Kurikulum terpadu dapat menghasilakan manusia sosial sebagai anggota masyarakat atas ikatan-ikatan budaya, agama, adat yang berhubungan secara dinamis, harmonis, baik hubungan vertikal maupun horizontal

Di dalam Undang-Undang Nomor 20 tahun 2003 tentang Sisdiknas pasal 1 ayat (1) dinyatakan pendidikan adalah usaha sadar dan terencana untuk mewujudkan suasana belajar dan proses pembelajaran agar peserta didik secara aktif mengembangkan potensi dirinya untuk memiliki kekuatan spritual keagamaan, pengendalian diri, kepribadian, kecerdasan, akhlak mulia, serta keterampilan yang diperlukan dirinya, masyarakat, bangsa dan negara.

Bentuk-bentuk kurikulum terpadu bisa mengacu dari konsep integrated curiculum, yang dapat dilakukan dengan bentuk. 1. Keterpaduan dalam satu disiplin ilmu. 2. Keterpaduan dalam lintas bidang studi. 3. Keterpaduan dalam dan lintas siswa.

\section{F. DAFTAR PUSTAKA}

al-Qur'an al-Kariim.

Ashraf, Ali.1996. Horizon Baru Pendidikan Islam.terj. Jakarta: Pustaka Firdaus

Departemen Pendidikan Nasional. Undang-Undang No. 20 Tahun 2003. Bandung: Citra Unbara

Freire, Paulo. 1985. Pendidikan Kaum Tertindas.Terj. Jakarta: LP3ES.

Fahmi Alaydroes. 2003. Pendidikan Terpadu. WWW. Islamika.com.

Mastuhu. 1994. Dinamika Sistem Pendidikan Pesantren. Jakarata: Inisi.

Muhaimin. 2009. Pengembangan Kurikulum Pendidikan Agama Islam. Jakarta: PT.Raja Grafindo Persada.

Muhaimin. 2009.Rekonstruksi Pendidikan Islam. Jakarta:PT.Raja Grafindo Persada.

Qardhawi, Yusuf. 2003. Ilmu Pengetahuan Dalam Perspektif Islam. Yogyakarta: Izzan Pustaka. 
Rahman, Fathur.2004. Pengembangan Sistem Pondok Pesantren Sebagai Sistem Pendidikan Terpadu.Bandung: Mimbar pustaka.

Syihab,Quraish. 2002. Membumikan al-Qur'an. Bandung: Mizan.

Tajab. 1999. Dasar-Dasar Kependidikan Dalam islam. Jakarta: Logos.

Zainudin. 2008. Paradigma Pendidikan Terpadu. Malang:UIN-Malang Press. 